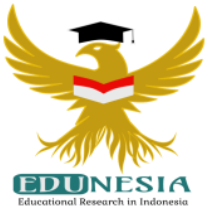

\title{
Development of Rubber Media Based Resistance Model for Sprint Runners in Riau
}

\author{
Septiandi Eka Putra1; Johansyah Lubis²; Novi Marlina Siregar ${ }^{3}$ \\ 1,2,3Physical Education, Universitas Negeri Jakarta, Indonesia \\ ${ }^{1}$ Corresponding Email: seputra22@gmail.com, Phone Number : 0811 xxxx xxxx
}

Article History:
Received: Apr 08, 2021
Revised: Apr 23, 2021
Accepted: Apr 30, 2021
Online First: May 05, 2021

Keywords:

Exercise Model, Rubber Media, Sprint Runner.

Kata Kunci:

Media Karet, Model Latihan, Pelari Sprint.

\section{How to cite: \\ Putra, S.E., Lubis, J., \& Siregar, N.M. (2021). Development of Rubber Media Based Resistance Model for Sprint Runners in Riau. Edunesia: Jurnal Ilmiah Pendidikan, 2 (2): 490-502.}

This is an open access article under the CC-BY-NC-ND license
Abstract: The aim of this study is to develop a rubber-based resistance training model for sprint athletes in Riau province by evaluating the efficacy of increasing sprint athletes' short distance running pace. The research method used in this study is ADDIE's research and development method, which consists of five steps. Athletes from Riau Province participated in this study as test subjects. analysis, design, development, implementation, and evaluating are the first steps in the research process. Three experts were present for the model feasibility test: two athletic lecturers and one national athletic coach. The model's efficacy was tested using a 60-meter speed parameter test involving 30 athletes from Riau Province, 15 of whom were in the experimental group and 15 of whom were in the control group. The difference test results from SPSS 22 showed that the experimental group had an average difference of 0.78 and the control group had an average difference of 0.12 . The discrepancy is derived from the test results, which are expressed in terms of time, so the shorter the time, the better. The discrepancy between the experimental and control groups' different values, or mean different $=0.658$, $\mathrm{t}$-count $=23.632, \mathrm{df}=28$, with $\mathrm{p}$-value $=$ $0.000<0.05$, indicates that there are substantial variations between the experimental and control groups. It can be concluded that the rubber media-based Resistance training model for Riau provincial sprint athletes is more successful and can help the Riau provincial sprint athletes improve their 100-meter running pace.

Abstrak: Penelitian ini bertujuan untuk mengembangkan model latihan Resistance berbasis media karet. Penelitian diawali dengan analysis, design, development, implementation dan evaluating. Penelitian ini menggunakan metode penelitian dan pengembangan (Research and Development/R \&D) dengan model pengembangan ADDIE, Adapun prosedur pengembangan ADDIE yaitu: analysis, design, develop, implementation, evaluate. Subjek penelitian pada penelitian ini adalah atlet cabang olahraga atletik di Provinsi Riau. Uji kelayakan model menghadirkan 3 ahli yang terdiri 2 orang dosen atletik dan 1 orang pelatih atletik nasional. Uji efektivitas model menggunakan tes parameter kecepatan 60 meter yang melibatkan 30 atlet atletik di Provinsi Riau yang mana 15 subjek sebagai kelompok eksperiman dan 15 subjek sebagai kelompok kontrol. Hasil uji perbedaan yang didapat dari SPSS 22 pada kelompok eksperimen dengan rata-rata nilai beda 0,78 dan pada kelompok kontrol dengan rata-rata nilai beda 0,12 , hasil selisih tersebut berasal dari penilaian tes yang berupa hasil waktu, jadi semakin kecil waktu yang diperoleh maka semakin baik. Selisih dari hasil nilai beda kelompok eksperimen dan kontrol atau mean different $=$ 0.658 , t-hitung $=23.632, \mathrm{df}=28$, dengan $\mathrm{p}$-value $=0,000<0,05$ maka dapat disimpulkan terdapat perbedaan yang signifikan pada kelompok eksperimen dan kontrol. Dapat disimpulkan bahwa model latihan Resistance berbasis media karet untuk atlet sprint provinsi riau yang dikembangkan memiliki efektivitas yang lebih tinggi dan dapat meningkatkan kecepatan lari 100 meter pada atlet sprint provinsi riau. 


\section{A. Introduction}

In athletics, the 100 meter short sprint is the most coveted number. The title of fastest individual has recently brought a sprinter into the public eye. Take a look at how Muhammad Zohri rose to prominence after winning the International Association of Athletics Federations (IAAF) U20 world championship in Finland. Being the fastest in short distance running is not easy, and achieving this goal requires strong cooperation from all stakeholders, including the government, coaches/teachers, athletes, and the community. From the seriousness of nurturing young seedlings or regenerating young talents, facilities and infrastructure are all important.

Athletics is a set of different sports that can be categorized into three categories: running, throwing, and jumping. Short distance running, medium distance running, and long distance running are the three divisions of race numbers in running.

Short-distance running, also known as sprinting, is a run that is completed at top speed from start to finish. $100 \mathrm{~m}, 200 \mathrm{~m}, 400 \mathrm{~m}$ distance running, $100 \mathrm{~m}$ women's hurdles, $110 \mathrm{~m}$ temple hurdles, $400 \mathrm{~m}$ hurdles, $4 \times 100 \mathrm{~m}$ relay races, and $4 \times 400 \mathrm{~m}$ relay races are all sprint events.

Running a short distance (sprint) necessitates the specification of the physical condition's elements, which is to run as quickly as possible while exerting all of his power from the start (starting from the start) to reaching the finish line (finish). Syafrudin (2011) stated that a 100 meter sprint needs components or elements of physical conditions such as (1) reaction speed to start, (2) speed strength up to the first 30 meters, (3) acceleration or acceleration from 30 meters to a distance of 80 meters, and (4) speed endurance in the last 20 meters in athletic activities (Henjilito, 2017).

As a result, many aspects of physical fitness are required just to produce a sprinter. This ensures that a short distance runner receives training not only for sprint speed, but also for all other aspects of physical fitness, such as strength training, response speed, and speed endurance.

According to Sukadiyanto (2010), "The main objective and target of training is to improve the abilities, skills and appearance of athletes with the guidance of a coach (Sucipto \& Widiyanto, 2016). Exercise is a systematic process and exercises that are repeated over and over again with increasing numbers of training loads and training intensity. Exercise is believed to provide the freshness of the body, which means that provide health care for the culprit (Budiman, 2016).

Lumintuarso (2013) said training is basically an educational process that aims to help individuals improve their cognitive, affective, and psychomotor abilities. sidik (2010) said To become a successful and potential sprinter, athletes must have good talent, but training can also be developed through biomotor abilities such as flexibility, strength (which is then developed into strength-speed/power), coordination, and resistance (which is then developed into endurance-speed).

Power, in addition to agility, is an important component and driving force when running to improve speed. Thus, strength must be practiced systematically and programmed, and strength plays an important role in shielding athletes from potential injuries; strength training can help reinforce the stability of the joints. and combining it with speed will generate power, or the ability to complete a task in the shortest amount of time, resulting in a positive impact on running speed results.

"Strength is one of the elements that must be owned by an athlete," says Bompa in Iskandar (2016), "because every success in sports often needs strength." Meanwhile, 
strength, or what is generally known as Strength, is described by Ismaryati (2011) as the force of muscle contraction achieved in a single maximum effort. A muscle or group of muscles exerts their full effort to overcome a resistance.

Contrast training is a resistance exercise that allows muscles to contract against external resistance in order to improve strength and endurance, according to Richard Weil, MD (2004) Rubber, damble, own body weight, wind, or any other object that causes the muscles to contract may be used as a source of resistance or obstacle. (Soegiyanto et al, 2012).

Kraemer et al (2002) "resistance training can improve health and components of physical fitness skills." The elements contained in health include endurance, muscle power, flexibility, body composition, hypertophy and aerobic capacity (Mardhika, 2017).

Resistance training, according to Martens (2004), can be used to improve not only strength but also endurance, control, and pace. This means that resistance training can be used to improve stamina, agility, and pace in addition to strength (Pranata et al, 2017).

\section{B. Method}

This study employs both qualitative and quantitative methods. The aim of the development research was to implement the findings of a rubber media-based training model for sprint athletes in the Riau province. Training products with requirements and effectiveness tests are developed through research.

This development study follows the ADDIE development steps, which are divided into five phases as shown in Figure 1.

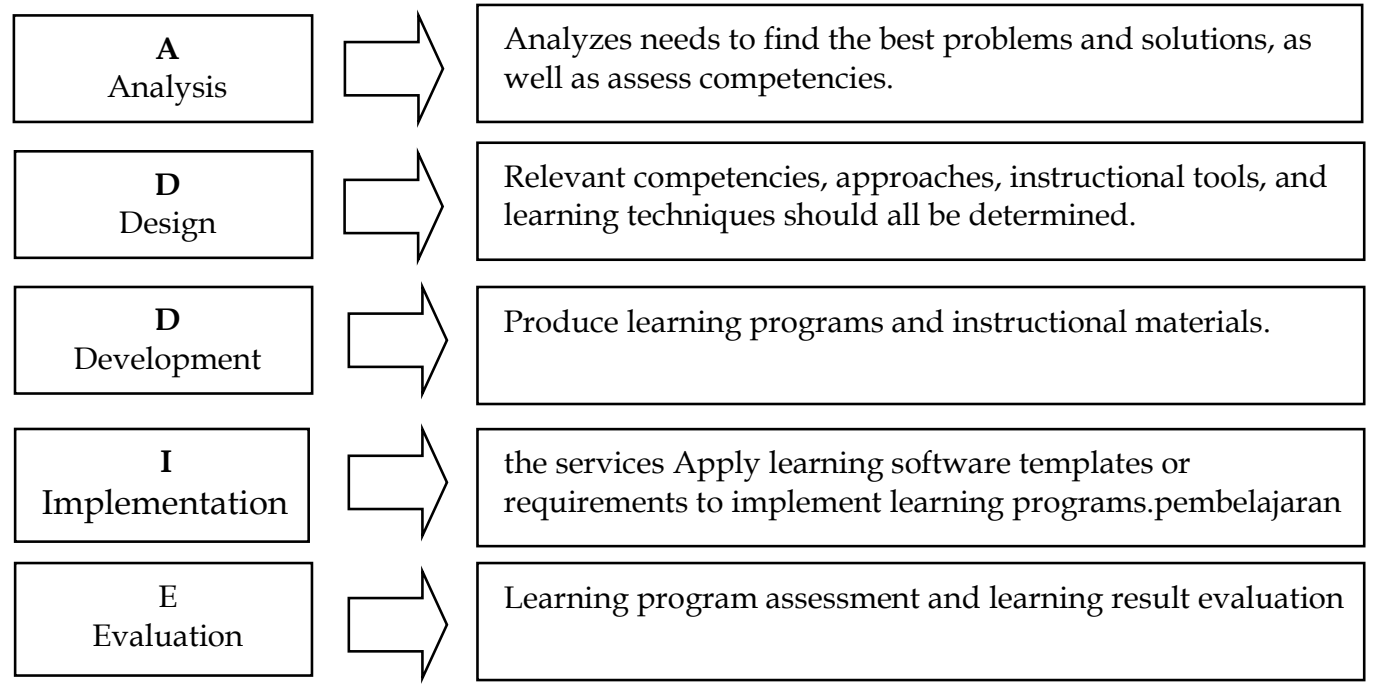

Figure 1. Steps in the ADDIE Research and Development Phase.

In this exercise, research and development is carried out using the ADDIE model (Pribadi, 2009), which consists of five phases (A) analysis, (D) design, (D) development, (I) implementation, and (E) evaluation (abbreviated as ADDIE)" (Fitriana et al., 2019).

a) Analysis: Study experiments, findings, field data analysis, observations, and process issues found in short distance running activities are used to conduct preliminary research.

b) The next stage to design: At this stage, the researcher creates and decides the template that will be used in the Sprint running training research model. 
c) The third stage development: This stage is completed after the product design has been completed; the next step is to produce the product in stages. This stage starts by putting all of the components from the previous stage together. The researcher then corrects the produced product until it is validated; once it is, the product is ready to be used validated by (expert judgment).

d) The fourth stage Implementation: The implementation stage was carried out on 30 sprinter athletes from the Riau province. During the trial, the researcher took notes on the flaws and limitations that remained after the product was implemented. A pretest is given before the exercise model is applied, and a posttest is given afterward to determine how effective the product is.

e) The fifth stage evaluation: Evaluation is a series of processes for analyzing a product at the implementation stage, it can be shortened to answer the question whether there are deficiencies / weaknesses. If there are no more revisions, the product is suitable for use and can be immediately published.

The data was analyzed in both qualitative and quantitative ways. After passing the small group trial time and expert testing, the efficacy evaluation was continued by performing the Pre-Test and Post-Test on the treated (experimental group) and untreated (control group) athletes, with a total of 30 athletes.

Interviews with coaches and expert advice were used to gather group trial data from four athletic clubs in Riau province, (1) 15-person small group trials, (2) 30-person efficacy testing.

\section{Result and Discussion}

The results of the creation of a rubber-based resistance training model for sprint athletes in Riau province aim to create an efficient and appealing speed training model, which is presented using data from needs analysis and trainer interviews. (validation expert) was collected from two lecturers at the State University of Jakarta's Faculty of Sports Science and one athletic national coach.

The following are the findings of a needs analysis conducted by interviewing two athletic coaches from each different club.

Table 1. Data from athletic coach interviews I

\begin{tabular}{cll}
\hline No & \multicolumn{1}{c}{ Question } & \multicolumn{1}{c}{ Answer } \\
\hline 1 & $\begin{array}{l}\text { How long have you been training } \\
\text { athletics? }\end{array}$ & $\begin{array}{l}\text { To begin with, I started my career as a coach } \\
\text { in 2010 }\end{array}$ \\
\hline 2 & $\begin{array}{l}\text { Where do you have the knowledge } \\
\text { or skills to train athletics? }\end{array}$ & $\begin{array}{l}\text { From my experience as an athlete and } \\
\text { supported by the knowledge I got through } \\
\text { upgrading level 1 athletic trainers and } \\
\text { physical training. }\end{array}$ \\
\hline 3 & $\begin{array}{l}\text { Is resistance training given to your } \\
\text { club? }\end{array}$ & Yes, give \\
\hline 4 & $\begin{array}{l}\text { How do you train using resistance } \\
\text { training? }\end{array}$ & $\begin{array}{l}\text { The exercise I gave was using a mini band } \\
\text { and pulling the harnes. }\end{array}$ \\
\hline 5 & $\begin{array}{l}\text { How enthusiastic are the athletes } \\
\text { when participating in resistance } \\
\text { training? }\end{array}$ & $\begin{array}{l}\text { Children are less enthusiastic about doing } \\
\text { the exercises. }\end{array}$ \\
\hline
\end{tabular}




\begin{tabular}{cll}
\hline No & \multicolumn{1}{c}{ Question } & \multicolumn{1}{c}{ Answer } \\
\hline 6 & $\begin{array}{l}\text { What resistance exercises do you } \\
\text { often give athletes? }\end{array}$ & By running to pull the iron 20-30 meters. \\
\hline 7 & $\begin{array}{l}\text { Have you ever used a rubber-based } \\
\text { resistance training model? }\end{array}$ & $\begin{array}{l}\text { Ever, but due to limitations of reference, the } \\
\text { new training model has used it several times }\end{array}$ \\
\hline 8 & $\begin{array}{l}\text { Is there a need to provide a more } \\
\text { varied and interesting rubber- } \\
\text { based resistance training model to } \\
\text { increase running speed? }\end{array}$ & $\begin{array}{l}\text { It is necessary because in my opinion an } \\
\text { attractive training model can make athletes } \\
\text { motivated in training }\end{array}$ \\
\hline
\end{tabular}

Table 2. Data from athletic coach interviews II

\begin{tabular}{cll}
\hline No & \multicolumn{1}{c}{ Question } & \multicolumn{1}{c}{ Answer } \\
\hline 1 & $\begin{array}{l}\text { How long have you been training } \\
\text { athletics? }\end{array}$ & $\begin{array}{l}\text { For the first time I started my career as a } \\
\text { coach in 2000 }\end{array}$ \\
\hline 2 & $\begin{array}{l}\text { Where do you have the knowledge } \\
\text { or skills to train athletics? }\end{array}$ & $\begin{array}{l}\text { From my experience as an athlete and some } \\
\text { training as an athletic trainer }\end{array}$ \\
\hline 3 & $\begin{array}{l}\text { Is resistance training given to your } \\
\text { club? }\end{array}$ & Yes I give it to the club \\
\hline 4 & $\begin{array}{l}\text { How do you train using resistance } \\
\text { training? }\end{array}$ & $\begin{array}{l}\text { Exercise I gave attracts harnes and ran } \\
\text { climbs run }\end{array}$ \\
\hline 5 & $\begin{array}{l}\text { How enthusiastic are the athletes } \\
\text { when participating in resistance } \\
\text { training? }\end{array}$ & $\begin{array}{l}\text { Children lackluster especially if the } \\
\text { movement is repeated again with the same } \\
\text { motion }\end{array}$ \\
\hline 6 & $\begin{array}{l}\text { What resistance exercises do you } \\
\text { often give athletes? }\end{array}$ & $\begin{array}{l}\text { by pulling the iron and ran climbs 30 meters } \\
\text { repeated until a number of reps and sets }\end{array}$ \\
\hline 7 & $\begin{array}{l}\text { Have you ever used a rubber-based } \\
\text { resistance training model? }\end{array}$ & $\begin{array}{l}\text { Never but limited to reference this form of } \\
\text { exercise }\end{array}$ \\
\hline 8 & $\begin{array}{l}\text { Is there a need to provide a more } \\
\text { varied and interesting rubber- } \\
\text { based resistance training model to } \\
\text { increase running speed? }\end{array}$ & $\begin{array}{l}\text { is very necessary in the presence of the } \\
\text { model interesting exercise can make athletes } \\
\text { excited about training, and for coaches need } \\
\text { a reference form of training }\end{array}$ \\
\hline
\end{tabular}

The model planning stage begins after the results of the needs review and field observations have been obtained. Prior to the small group trial, the model planning stage was completed. Planning and modeling are steps that are taken to ensure that research and development is carried out with clarity. In the first phase, the researcher created a training model product based on resistance rubber media for sprint athletes in Riau province. From 23 training model products, the researcher produced a standardized product design.

Following the collection of needs analysis data and obtaining the required data for the creation of a rubber-based resistance training model for Riau provincial sprint athletes, the next step is to perform expert tests with the aim of determining the model's feasibility or validity based on expert evaluation and advice. The researcher presented three experts in the feasibility evaluation of the rubber media-based resistance training model for Riau province sprint athletes: one lecturer in motion biomechanics (Dr. Johansyah Lubis, M.Pd), 
one lecturer in physical activities (Drs. Mustara, M.Pd), and one senior athletic winner in Riau province (Hasnor Nursahi).

Table 3. Expert recapitulation of athletes and coaches

\begin{tabular}{|c|c|c|c|c|c|c|}
\hline \multirow[b]{2}{*}{ No } & \multirow[b]{2}{*}{ Exercise Model } & \multicolumn{4}{|c|}{ Validation } & \multirow{2}{*}{$\begin{array}{l}\text { Peecentage } \\
\text { Unfeasible }\end{array}$} \\
\hline & & Leacture 1 & Leacture 2 & $\begin{array}{c}\text { Athletichs } \\
\text { Coach }\end{array}$ & Feasible & \\
\hline \multicolumn{7}{|c|}{ A. Training Model of Running Technique } \\
\hline 1 & High Knee & Feasible & Feasible & Feasible & $100 \%$ & $0 \%$ \\
\hline 2 & Back Lunges & Feasible & Feasible & Feasible & $100 \%$ & $0 \%$ \\
\hline 3 & Single Leg High Knee & Feasible & Feasible & Unfeasible & $66.7 \%$ & $33.3 \%$ \\
\hline 4 & Side High Knee & Feasible & Feasible & Feasible & $100 \%$ & $0 \%$ \\
\hline 5 & Resistance High Knee & Feasible & Feasible & Feasible & $100 \%$ & $0 \%$ \\
\hline 6 & Resistance Kicking & Feasible & Feasible & Feasible & $100 \%$ & $0 \%$ \\
\hline 7 & Resistance Heel Kick & Feasible & Feasible & Feasible & $100 \%$ & $0 \%$ \\
\hline 8 & Resistance Circle High Knee & Feasible & Feasible & Feasible & $100 \%$ & $0 \%$ \\
\hline 9 & Resistance Circle Kicking & Feasible & Feasible & Feasible & $100 \%$ & $0 \%$ \\
\hline 10 & Resistance Circle Heel Kick & Feasible & Feasible & Feasible & $100 \%$ & $0 \%$ \\
\hline \multicolumn{7}{|c|}{ B. Model of Start Exercise } \\
\hline 11 & Sliding Leg & Feasible & Feasible & Feasible & $100 \%$ & $0 \%$ \\
\hline 12 & Back To Back Lunges & Feasible & Feasible & Feasible & $100 \%$ & $0 \%$ \\
\hline 13 & Swing Arm Lunges & Feasible & Feasible & Feasible & $100 \%$ & $0 \%$ \\
\hline 14 & $\begin{array}{l}\text { R-BSY (Resistance Bersedia } \\
\text { Siap Yak) }\end{array}$ & Feasible & Feasible & Feasible & $100 \%$ & $0 \%$ \\
\hline 15 & Swing Arm & Feasible & Feasible & Feasible & $100 \%$ & $0 \%$ \\
\hline 16 & Push Drive & Unfeasible & Unfeasible & Feasible & $33.3 \%$ & $66.7 \%$ \\
\hline \multicolumn{7}{|c|}{ C. Model of Acceleration Exercise } \\
\hline 17 & Tarik Lepas & Feasible & Feasible & Feasible & $100 \%$ & $0 \%$ \\
\hline 18 & Halang $W$ & Feasible & Feasible & Feasible & $100 \%$ & $0 \%$ \\
\hline 19 & Lari Bolak Balik & Unfeasible & Unfeasible & Unfeasible & 0 & $100 \%$ \\
\hline 20 & Slide Running & Feasible & Feasible & Feasible & $100 \%$ & $0 \%$ \\
\hline 21 & Forward Jumping & Feasible & Feasible & Feasible & $100 \%$ & $0 \%$ \\
\hline \multicolumn{7}{|c|}{ D. Model of Max Speed Exercise } \\
\hline 22 & Max Speed Resistance Sprint & Feasible & Feasible & Feasible & $100 \%$ & $0 \%$ \\
\hline 23 & $\begin{array}{l}\text { Max Speed Resistance Sprint } \\
\text { Three Angel }\end{array}$ & Feasible & Feasible & Feasible & $100 \%$ & $0 \%$ \\
\hline \multirow{3}{*}{\multicolumn{2}{|c|}{ Total }} & \multicolumn{3}{|c|}{ Total number of training items } & 23 & item \\
\hline & & \multicolumn{3}{|c|}{\begin{tabular}{|l|} 
Eligible category items \\
\end{tabular}} & 21 & item \\
\hline & & \multicolumn{3}{|c|}{ Inappropriate category items } & 2 & item \\
\hline
\end{tabular}


Table 4. Percentage of validation report

\begin{tabular}{cccccc}
\hline No & Experts & $\begin{array}{c}\text { Minimum } \\
\text { Score }\end{array}$ & $\begin{array}{c}\text { Maximum } \\
\text { Score }\end{array}$ & Result & Persentase \\
\hline 1 & $\begin{array}{c}\text { Athletic Leactures } \\
\text { (Jakarta University) }\end{array}$ & 0 & 23 & 21 & $91.3 \%$ \\
\hline 2 & $\begin{array}{c}\text { Biomechanics Leactures } \\
\text { (Jakarta University) }\end{array}$ & 0 & 23 & 21 & $91.3 \%$ \\
\hline 3 & Senior Athletic Coach & 0 & 23 & 21 & $91.3 \%$ \\
\hline \multicolumn{7}{r}{ Average } & & & $\mathbf{9 1 . 3 \%}$ \\
\hline
\end{tabular}

The average percentage of validation reports from athletic and coaching experts is $91.3 \%$, indicating that the overall product produced is very feasible. Athletic experts and athletic coaching have contributed some details. The following is a description of the given input:

The first piece of advice from a motion biomechanics specialist (Dr. Johansyah Lubis, M.Pd) was to (A) align the training model with short-distance running concepts (B) align the basic training model, such as running, with the principles of long-distance running (C) provide an example of an easy-to-understand training model (D) When pairing, change the scale of the athletes' bodies. (E) Pay close attention to the athlete's movement technique when he or she performs the exercise.

Second piece from the athletic expert (Drs. Mustara, M.Pd): (A) arrange and sequence the exercises from basic to complicated movements (B) adjust the training model for the test distance parameters to be used (C) mark the areas exercise (D) give it a catchy name (E) the points of the exercise should be clear.

The athletic coaching expert's third contribution (Hasnor Nursahi) (A) Directions for implementation must be made more clearly so that athletes can understand them. (B) The model created helps athletes want to do it. (C) Training must be entirely safe for athletes. (D) Coaching points of training must include sprint training components.

The effectiveness test is the next step, which determines how successful the product is. Pre and post tests are used to evaluate the efficacy of the built model.

The researchers used 30 athletes from the Riau Province athletic training center to assess the efficacy of the resistance training model based on rubber media. The following table contains information on the outcomes of 30 athlete evaluations on the model's effectiveness:

Table 5. Results of the 60-meter running speed test in the experiment group before and after treatment (Pretest and Posttest).

\begin{tabular}{cccc}
\hline Subjek & Pre-Test & Post-Test & Different \\
\hline Subjek 1 & 7.6 & 6.87 & 0.73 \\
Subjek 2 & 7.25 & 6.57 & 0.68 \\
Subjek 3 & 7.83 & 7.15 & 0.68 \\
Subjek 4 & 7.55 & 6.83 & 0.72 \\
Subjek 5 & 7.02 & 6.2 & 0.82 \\
\hline
\end{tabular}




\begin{tabular}{cccc}
\hline Subjek & Pre-Test & Post-Test & Different \\
\hline Subjek 6 & 7.84 & 7.08 & 0.76 \\
Subjek 7 & 7.55 & 6.83 & 0.72 \\
Subjek 8 & 8.02 & 7.24 & 0.78 \\
Subjek 9 & 7.9 & 7.13 & 0.77 \\
Subjek 10 & 7.57 & 6.84 & 0.73 \\
Subjek 11 & 9.03 & 8.12 & 0.91 \\
Subjek 12 & 8.1 & 7.32 & 0.78 \\
Subjek 13 & 9.2 & 8.26 & 0.94 \\
Subjek 14 & 8.26 & 7.45 & 0.81 \\
Subjek 15 & 8.43 & 7.55 & 0.88 \\
\hline Average & 7.94 & 7.16 & $\mathbf{0 . 7 8}$ \\
\hline
\end{tabular}

The results of the experimental group of athletes' pre-test and post-test while performing a 60-meter running speed test are shown in the table above. Before implementing the 21 things of the Resistance exercise model based on rubber media, a pretest was conducted. The evaluation was carried out to assess the athlete's initial and final abilities after 16 meetings of therapy. The average test score for 15 athletes who were treated on a regular basis was 7.94. The athlete's running speed increases markedly after being treated with the Resistance training model based on rubber media for as many as 21 products of the training model, as shown by an improvement in the average record result, namely 7.16.

According to the above definition, there is a difference in the 60 meter running speed results between the pre-test and post-test, indicating that the training model produced is successful at increasing short distance running speed.

Table 6. Experimental Group Results of Paired Sample Statistical Treatment (pre-test) and (post-test)

\begin{tabular}{|c|c|c|c|c|c|c|c|c|}
\hline \multicolumn{9}{|c|}{ Paired Samples Test } \\
\hline & \multicolumn{5}{|c|}{ Paired Differences } & \multirow{3}{*}{$\mathrm{t}$} & \multirow{3}{*}{$\mathrm{df}$} & \multirow{3}{*}{$\begin{array}{l}\text { Sig. (2- } \\
\text { tailed) }\end{array}$} \\
\hline & \multirow[t]{2}{*}{$\begin{array}{c}\text { Mea } \\
\mathrm{n}\end{array}$} & \multirow[t]{2}{*}{$\begin{array}{l}\text { Std. } \\
\text { Deviati } \\
\text { on }\end{array}$} & \multirow{2}{*}{$\begin{array}{l}\text { Std. } \\
\text { Error } \\
\text { Mean }\end{array}$} & \multicolumn{2}{|c|}{$\begin{array}{c}\text { 95\% Confidence } \\
\text { Interval of the } \\
\text { Difference }\end{array}$} & & & \\
\hline & & & & Lower & Upper & & & \\
\hline $\begin{array}{ll}\text { Pai } & \text { Pre test - } \\
\text { r } 1 & \text { Post test }\end{array}$ & $\begin{array}{c}.780 \\
67\end{array}$ & .07914 & .02043 & .73684 & .82450 & $\begin{array}{c}38.2 \\
03\end{array}$ & 14 & .000 \\
\hline
\end{tabular}


The difference between the pre-test and post-test results is shown by the mean $=$ 0.780 in the mean difference test with SPSS, with the results of $t$-count $=38.203, \mathrm{df}=14$ and $\mathrm{p}$-value $=0.000 .05$, indicating that there is a significant difference between before and after. Resistance exercise with rubber media is the given treatment model.

Based on these findings, it can be concluded that the rubber media resistance training model is successful in increasing the athlete's running pace. The exercise model that was created is extremely accurate.

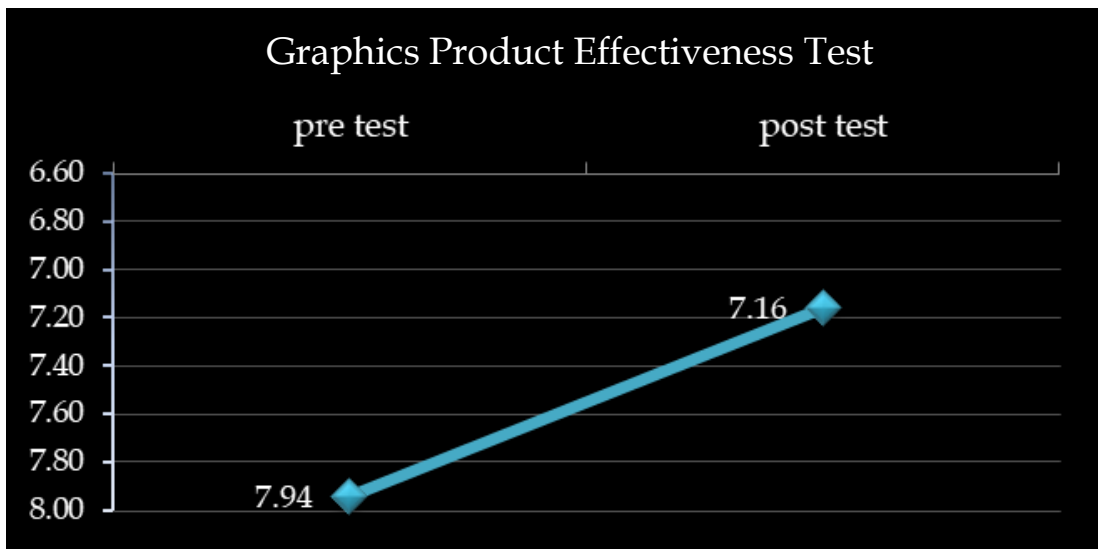

Figure 2. Graphics product effectiveness test experiment

The comparison chart above shows the average record results of the Resistance training model based on rubber media before and after treatment, with an average outcome of 7.94 seconds for Pre-test and 7.16 seconds for Post-test.

In addition, the following table shows the outcomes of the tests performed on 15 athletes in the control group:

Table 7. Results of the 60-meter running speed test in the control group before and after treatment (pretest and posttest).

\begin{tabular}{ccc}
\hline Subjek & Pre-Test & Post-Test \\
\hline Subjek 1 & 7.25 & 7.10 \\
Subjek 2 & 7.10 & 7.01 \\
Subjek 3 & 7.71 & 7.62 \\
Subjek 4 & 7.45 & 7.30 \\
Subjek 5 & 7.56 & 7.40 \\
Subjek 6 & 8.00 & 7.92 \\
Subjek 7 & 7.40 & 7.32 \\
Subjek 8 & 7.79 & 7.72 \\
Subjek 9 & 8.20 & 8.12 \\
\hline
\end{tabular}




\begin{tabular}{ccc}
\hline Subjek & Pre-Test & Post-Test \\
\hline Subjek 10 & 7.22 & 7.14 \\
Subjek 11 & 8.30 & 8.20 \\
Subjek 12 & 7.60 & 7.51 \\
Subjek 13 & 8.26 & 7.90 \\
Subjek 14 & 8.24 & 8.08 \\
Subjek 15 & 7.80 & 7.71 \\
\hline Average & 7.73 & 7.60 \\
\hline
\end{tabular}

Table 8. Experimental group results of paired sample statistical treatment (pre-test) and (post-test)

\begin{tabular}{|c|c|c|c|c|c|c|c|c|}
\hline \multicolumn{9}{|c|}{ Paired Samples Test } \\
\hline & \multicolumn{5}{|c|}{ Paired Differences } & \multirow{3}{*}{$\mathrm{t}$} & \multirow{3}{*}{$\mathrm{df}$} & \multirow{3}{*}{$\begin{array}{c}\text { Sig. } \\
(2- \\
\text { tailed) }\end{array}$} \\
\hline & \multirow[t]{2}{*}{$\begin{array}{l}\mathrm{Me} \\
\text { an }\end{array}$} & \multirow[t]{2}{*}{\begin{tabular}{|c} 
Std. \\
Deviat \\
ion
\end{tabular}} & \multirow[t]{2}{*}{$\begin{array}{l}\text { Std. } \\
\text { Error } \\
\text { Mean }\end{array}$} & \multicolumn{2}{|c|}{$\begin{array}{c}95 \% \\
\text { Confidence } \\
\text { Interval of the } \\
\text { Difference } \\
\end{array}$} & & & \\
\hline & & & & Lower & Upper & & & \\
\hline $\begin{array}{cc}\text { Pair } & \text { Pre Test - } \\
1 & \text { Post Test }\end{array}$ & $\begin{array}{c}.122 \\
00\end{array}$ & .07341 & .01895 & .08135 & .16265 & $\begin{array}{c}6.43 \\
7\end{array}$ & 14 & .000 \\
\hline
\end{tabular}

The pre-test results of athletes while doing the real 60 meter running speed test are based on the table above and the SPSS results. The average pre-test result was 7.73, and the average post-test result was 7.60 for 15 athletes. There is a significant correlation even though the correlation coefficient is $0.00<0.05$ The pre-test data for normality is 0.323 , while the post-test results are 0.564 , indicating that both data are greater than 0.05 . It denotes that the two sets of data are drawn from a population with a normal distribution. The pre-test mean score was 7.72, and post test mean score was 7.60, indicating that there was a small but substantial improvement due to the lack of care. 


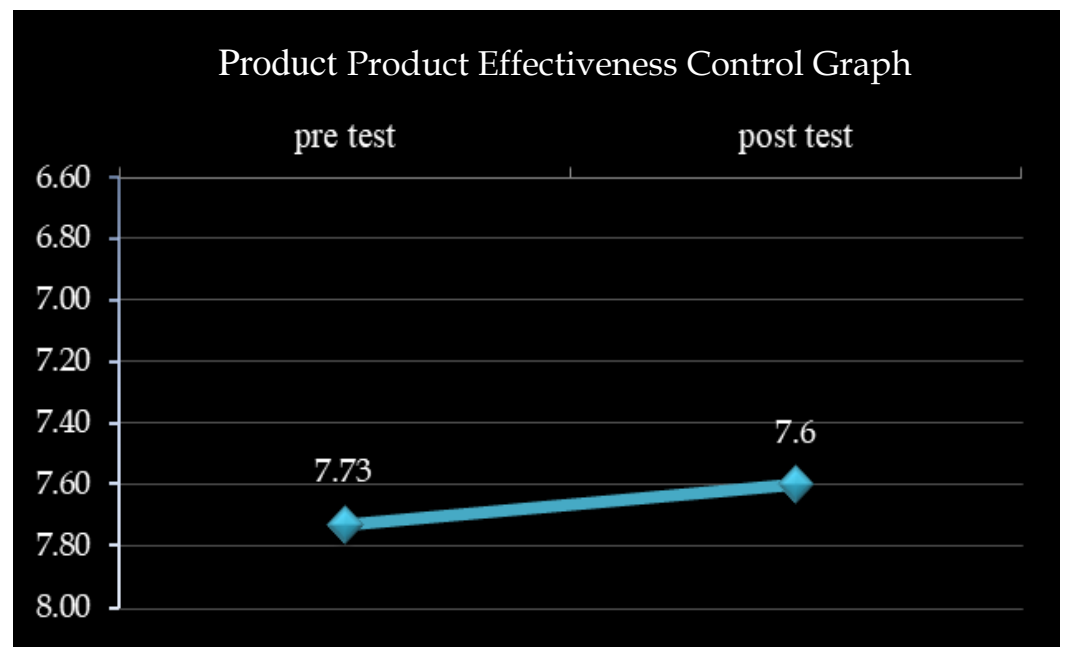

Figure 3. Product effectiveness control graph

The comparison chart above shows the average record data of the Resistance training model based on rubber media before and after treatment, with an average pre-test of 7.73 seconds and a post-test of 7.60 seconds.

Table 9. Experimental group results of paired sample statistical treatment (pre-test) and (post-test)

\begin{tabular}{|c|c|c|c|c|c|}
\hline \multicolumn{6}{|c|}{ Group Statistics } \\
\hline \multirow{2}{*}{ Value } & Class & $\mathrm{N}$ & Mean & $\begin{array}{c}\text { Std. } \\
\text { Deviation }\end{array}$ & $\begin{array}{c}\text { Std. Error } \\
\text { Mean }\end{array}$ \\
& Eksperimen & 15 & .7807 & .07914 & .02043 \\
& Kontrol & 15 & .1220 & .07341 & .01895 \\
\hline
\end{tabular}


Table 9. Independent samples test

\begin{tabular}{|c|c|c|c|c|c|c|c|c|c|c|}
\hline \multicolumn{11}{|c|}{ Independent Samples Test } \\
\hline & & \multicolumn{2}{|c|}{$\begin{array}{c}\text { Levene's Test } \\
\text { for Equality of } \\
\text { Variances } \\
\end{array}$} & \multicolumn{7}{|c|}{ t-test for Equality of Means } \\
\hline & & \multirow[t]{2}{*}{$F$} & \multirow[t]{2}{*}{ Sig. } & \multirow[t]{2}{*}{$t$} & \multirow[t]{2}{*}{ Df } & \multirow{2}{*}{$\begin{array}{l}\text { Sig } \\
\cdot \\
(2- \\
\text { tail } \\
\text { ed) }\end{array}$} & \multirow[t]{2}{*}{$\begin{array}{l}\text { Mean } \\
\text { Differ } \\
\text { ence }\end{array}$} & \multirow[t]{2}{*}{$\begin{array}{l}\text { Std. } \\
\text { Error } \\
\text { Differ } \\
\text { ence }\end{array}$} & \multicolumn{2}{|c|}{$\begin{array}{c}95 \% \\
\text { Confidence } \\
\text { Interval of the } \\
\text { Difference }\end{array}$} \\
\hline & & & & & & & & & Lower & Upper \\
\hline \multirow[b]{2}{*}{ Value } & $\begin{array}{c}\text { Equal } \\
\text { variances } \\
\text { assumed }\end{array}$ & .395 & .535 & $\begin{array}{c}23.63 \\
2\end{array}$ & 28 & $\begin{array}{c}.00 \\
0\end{array}$ & .65867 & .02787 & .60157 & .71576 \\
\hline & $\begin{array}{c}\text { Equal } \\
\text { variances } \\
\text { not } \\
\text { assumed }\end{array}$ & & & $\begin{array}{c}23.63 \\
2\end{array}$ & $\begin{array}{c}27.84 \\
3\end{array}$ & $\begin{array}{c}.00 \\
0\end{array}$ & .65867 & .02787 & 60156 & .71577 \\
\hline
\end{tabular}

Based on the findings of the difference test, it can be inferred that the difference between the experimental group's average difference value of 0.78 and the control group's average difference value of 0.12 came from the test measurement in the form of time results in the experimental group. The faster you can get there, the better. With a p-value of $0.000<$ 0.05 and a difference between the mean different outcomes $=0.658, \mathrm{t}$-count $=23.632, \mathrm{df}=28$, it can be assumed that there are substantial variations between the experimental and control groups.

The results show that the experimental group's therapy, namely the Resistance training model based on rubber media, is more successful and can improve running speed. Meanwhile, the control group, which received only the old training model medication, performed less well than the experimental group.

\section{Conclusion}

As a result of the data gathered, the researcher draws a range of conclusions, including that the product of the Resistance training model based on rubber media that is produced involves goals, implementation, services, and training points, as well as a training program based on established theories. The product includes 21 workout models that have been checked by experts. Furthermore, the rubber-based resistance training model is feasible and efficient for increasing short-distance running speed. With a p-value of $0.000<0.05$ and a difference between the mean different outcomes $=0.658, \mathrm{t}$-count $=23.632, \mathrm{df}=28$, it can be assumed that there are substantial variations between the experimental and control groups. 


\section{References}

Bompa, T. O., \& Haff, G. G. (2009). Periodization: Theory and Methodology of Training. United States of America: Human Kinetics.

Budiman, I.A, (2016). Development model of volleyball spike training. International Journal of Physical Education, Sports and Health. 466-471. Doi:-

Fitriana, N., Muhandaz, R., \& Risnawati, R. (2019). Pengembangan Modul Matematika Berbasis Learning Cycle 5E untuk Memfasilitasi Kemampuan Pemecahan Masalah Matematis Siswa Sekolah Menengah Pertama (SMP). JURING (Journal for Research in Mathematics Learning), 2(1), 021. https:// doi.org/10.24014/juring.v2i1.7496.

Henjilito, R. (2017). Pengaruh Daya Ledak Otot Tungkai, Kecepatan Reaksi Dan Motivasi Terhadap Kecepatan Lari Jarak Pendek 100 Meter Pada Atlet PPL Provinsi Riau. Journal Sport Area, 2(1), 70. https://doi.org/10.25299/sportarea.2017.vol2(1).595.

Ismaryati. (2011). Tes $\mathcal{E}$ Pengukuran Olahraga. Surakarta: LPP dan UNS press.

Lumintuarso, R. (2013). Teori Kepelatihan Olahraga, Jakarta: Lankor Kemenpora.

Mardhika, R. (2017). Pengaruh Latihan Resistance dan pyometric terhadap kekuatan otot tungkai dan kelincahan pada pemain futsal. Jurnal Wahana. 5-12. doi: -

Pranata, L. D., Yarmani, Y., \& Sugihartono, T. (2017). Pengaruh Latihan Beban Gaya-Pegas Karet Ban Terhadap Kecepatan Pukulan Kumite Gyaku Tzuki Untuk Atlet Karate Inkanas Kota Bengkulu. Jurnal Ilmiah Pendidikan Jasmani, 1(2), 106-110.

Soegiyanto, K. S., Lumintuarso, R., \& Rahayu, S. (2012). Pengaruh Metode Latihan, Bentuk Latihan Kecepatan dan Kelincahan terhadap Prestasi Lari 100 Meter. Media Ilmu Keolahragaan Indonesia, 2(1).

Sucipto, E., \& Widiyanto, W. (2016). Pengaruh Latihan Beban Dan Kekuatan Otot Terhadap Hypertrophy Otot Dan Ketebalan Lemak. Jurnal Keolahragaan. 111-121. doi: -

Zafar, S.D. (2010). Mengajar dan Melatih Atletik. PT. Remaja Rosdakarya. Bandung. 